6 Collier, B., and Lang, C., Can. J. Physiol, Pharmac., 47, 119-126 (1969).

7 Fonnum, F., Biochem. J., 113, 291-298 (1969).

Birks, R. I., and MacIntosh, F. C., Can. J. Biochem. Physiol., 39, 787-827 (1961).

9 Holton, P., and Ing, H. R., Br. J. Pharmac. Chemother., 4, 190-196 (1949).

\section{Immunoreactive thyrotrophin releasing factor in gastropod circumoesophageal ganglia}

REPORTS have indicated that thyrotrophin releasing factor (TRF) is stored in extrahypothalamic as well as hypothalamic brain regions of many vertebrates from the primitive larval lamprey to the more advanced mammals ${ }^{1-4}$. Although TRF is found in the brain of many poikilotherms, administration of synthetic TRF ( $\mathrm{Glu}-\mathrm{His}-\mathrm{ProNH}_{2}$ ) to these animals does not activate thyroid gland function ${ }^{5-7}$. Thus, it has been proposed that, in these animals, TRF modulates synaptic transmission rather than releasing thyrotrophin (thyroid stimulating hormone) ${ }^{\mathrm{I}}$. Furthermore, the administration of TRF to hypophysectomised rodents potentiates the effect of the L-dopa on behaviour ${ }^{8}$, thus supporting the hypothesis that TRF modulates monoaminergic transmission in higher vertebrates as well. Further support for a role of TRF in synaptic transmission is the finding that administration of the synthetic tripeptide leads to an increase in noradrenaline turnover in rat brain ${ }^{\theta-11}$. Because these reports imply first, that TRF may influence monoaminergic transmission and second, that, in lower vertebrates, this role of TRF may be more important than that of regulating TSH release, we have investigated whether TRF is present in invertebrates which do not produce thyroid hormones but exhibit monoaminergic neurotransmission. We found immunoreactive TRF in the circumoesophageal ganglia of various gastropods. Species studied were the landsnail Mesodon roemeri (Connecticut Valley Biological Supply Co., Massachusetts), Planorbis corneus (Mogul Ed Corp., Wisconsin), Helesoma trivolbis and Viviparus malleatus (Ann Arbor Biological Center, Michigan).

The circumoesophageal ganglia were removed and freed of excess connective tissue under a dissecting microscope. The ganglia were frozen immediately and tissues from several animals were pooled. After thawing, they were homogenised in $100 \mu 1$ of distilled water, and proteins were precipitated with $1.0 \mathrm{ml}$ of absolute methanol. After refrigeration overnight, the homogenate was centrifuged at $15,000 \mathrm{~g}$ for $5 \mathrm{~min}$ and the protein concentration of the pellet was determined according to the technique of Lowry et al. ${ }^{12}$. The methanolic phase was dried under nitrogen and resuspended in phosphate buffer for radioimmunoassay of TRF. The presence of immunoreactive TRF was determined by the method of Jackson and Reichlin ${ }^{1}$ or by a modification of the method of Jeffcoate et $\mathrm{al}^{13}$, to be described in detail elsewhere. Both assays showed minimal crossreactivities with TRF breakdown products and structurally related small peptides. The TRF determination in both assays, although carried out with different antibodies, were in good agreement (for example, $125 \mathrm{pg} \mathrm{mg}^{-1}$ protein compared with $150 \mathrm{pg} \mathrm{mg}^{-1}$ protein for a pool of ganglia).

Table 1 Immunoreactive TRF in various gastropods

$\begin{array}{lc}\text { Gastropod species } & \text { pg TRF } \mathrm{mg}^{-1} \text { protein } \\ \text { Viviparus malleatus } & 31.5(23-40)^{*} \\ \text { Helesoma trivolbis } & 65.0^{\dagger} \\ \text { Planorbis corneus } & 37.0^{\dagger} \\ \text { Mesodon roemeri } & 308.0(75-720) \ddagger\end{array}$

*Mean of two pools of ganglia; the range is indicated in parentheses.

†Determination of a single pool of ganglia.

¥Mean of four pools of ganglia; the range is indicated in parentheses.
Table 1 shows that TRF was present in various gastropods from the most primitive species examined ( $V$. maileatus) to the more advanced pulmonates $(H$. trivolbis, $P$. corneus, $M$. roemeri). There was more TRF in circumoesophageal ganglia from the landsnail Mesodon roemeri than that in those from water snails (mean value of $308 \mathrm{pg} \mathrm{mg}^{-1}$ protein compared with a pooled mean value of $44.5 \mathrm{pg} \mathrm{mg}^{-1}$ protein). The amount of TRF in pooled snail ganglia was less than has been reported for hypothalamic tissue of various vertebrates ${ }^{1}$, but was within the range of values reported for cerebral cortical tissues $\left(20 \mathrm{pg} \mathrm{mg}^{-1}\right.$ protein in the rat to $4,500 \mathrm{pg} \mathrm{mg}^{-1}$ protein in the tadpole $\mathrm{e}^{1}$ ). Although not shown in Table 1, immunoreactive TRF was present in extracts from Mesodon roemeri after the methanolic extracts from the circumoesophageal ganglia had been purified on a column of Sephadex SP C-25 according to the method of $\mathrm{McKelvy}^{13}$. This indicates that the immunoreactive material found in crude methanolic extracts from these animals is the tripeptide pGlu-HisProNH ${ }_{2}$. In further support of the identity of the immunoreactive material as TRF is the fact that the immunoreactive material from snail ganglia and synthetic TRF showed parallel dilution curves in the radioimmunoassay systems used.

Thus immunoreactive TRF is present in various gastropod species. This supports the evidence obtained from mammals that this molecule has a role in modulating neurotransmission, and suggests that this function evolved before that of controlling the release of thyroid stimulating hormone.

This work was supported by grants from the National Institutes of Health and the US National Science Foundation.

YVONNE GRIMM-JØRGENSEN JEFFREY F. MCKELVY

Department of Anatomy,

University of Connecticut Health Center,

Farmington, Connecticut 06032

\section{IVOR M. D. JACKSON}

Endocrine Unit,

Tufts, New England Medical Center Hospitals,

Boston, Massachusetts 02111

Received January 24, 1975.

Jackson, I. M. D., and Reichlin, S., Endocrinology, 95, 816-824 (1974)

Oliver, C., Eskay, R. L., Ben-Jonathan, N., and Porter, J. C., Endocrinology, 95, 540-546 (1974).

Jackson, I, M. D., and Reichlin, S., Life Sci., 14, 2259-2266 (1974).

4 Grimm-Jørgensen, Y., and McKelvy, J. F., J. Neurochem., 23, 471-478 (1974),

5 Gorbman, A., and Hyder, M., Gen. comp. Endocr., 20, 588-589 (1973).

6 Vandesande, F., and Aspeslagh, M. R., Gen. comp. Endocr., 23. 355-356 (1974).

Piotnikoff, N. P., Prange, A. F. Jr., Breese, G. R., Anderson, M. S., and Wilson, I.C., Science, 178, 417-418 (1972)

Keller, H. H., Bartholini, G., and Pletschner, A., Nature, 248, 528-529 (1974).

Horst, W. D., and Spirit, N., Life Sci., 15, 1073 . 1082 (1974).

1 Constantinidis, J., Geissbuhler, F., Gaillard, J. M., Havaguimian, T., and Tissot, R., Experientia, 30, $1182-1183$ (1974).

Lowry, O. H., Rosebrough, N. J., Farr, A. L., and RandalI, R. J., J. hiol. Chem. $193,265-275$ (1951).

13 Jeffcoate, S. L., Fraser, H. M., Gunn, A., and White, N., J. Endocr., 59, 191-192

(1973).
4 McKelvy, J. F., Analyt. Biochem. (in the press).

\section{Possible placental origin of ACTH in normal human pregnancy}

Ir is well known that the free fraction of plasma cortisol is increased in pregnancy ${ }^{1}$, but it has not been established whether this is a result of maternal pituitary or placental adrenocorticotrophic hormone (ACTH) secretion. Maternal plasma ACTH levels in human pregnancy have been variously reported as elevated $^{2}$, or depressed ${ }^{3}$; but there is no information on the relationship between ACTH levels and the stage of gestation. We now report that maternal ACTH levels increase progressively throughout pregnancy, that urinary free cortisol levels are raised and show resistance to suppression by dexamethasone 